\title{
Port of Ferrol enlargement works, Spain
}

Ignacio de la Peña Zarzuelo

Head of the Investment and Planning Director, Ferrol - San Cibrao Port

Authority, Muelle Curuxerias s/n, Ferrol, A Coruña, Spain

The Port of Ferrol is in the autonomous region of Galicia, in the north-west of the Iberian peninsula, in the ria of the same name. The port has traditionally specialised in bulk goods, mainly coal, scrap and petroleum products. An increase in traffic in the 1990s, combined with the diversification policy in the port authority activities, and the advisability to have a new container terminal, led the Port Authority to consider a major expansion project in the outer part of the ria. This paper provides an account of the works that were involved in this project (carried on from 2001 to 2005), known as the 'Port of Ferrol enlargement works (outer harbour) - 1st stage' and describes all the main construction processes (quarry, construction of breakwater, wharf, dredging processes, etc.) including the technological advances introduced at these works.

\section{Description of the works}

The works took place in the so-called Ensenada de Caneliñas (Caneliñas Inlet; Figure 1), where they are sheltered from the biggest waves rolling in from the North Atlantic Ocean (NW) by way of Cabo Prioriño Chico, which means that the design waves for designing the breakwater come from the west and are rather moderate $\left(H_{\mathrm{s} 90}=7 \cdot 6 \mathrm{~m}\right.$ for $T=281$ years $)$.

When selecting the ideal site, apart from the above-mentioned 'shelter' aspect, the following were considered: environmental questions, maritime and land access, the availability of natural depths, the quality of the quarry which would make it possible to supply the site with the materials required to perform the works, the fact that it had to be a safe distance from human settlements, compatibility with the urban development plans and the availability of low-cost land (see Grassa Garrido et al. (2009) for further details of the design studies).

The drawbacks inherent to the site are that it has neither road nor rail access, and that the electricity, water supply and telecommunications services were inadequate, so it was necessary to undertake supplementary actions in this respect.

The estimate for carrying out the infrastructure works at the first stage amounted to $€ 135$ million, plus a further $€ 45$ million for supplementary works, equipment and environmental restoration work. The deadline for carrying out the entire project was 44 months.

By way of a summary, these works are listed here.

(a) A $1040 \mathrm{~m}$ long rubblemound breakwater sloping at 57\% (1 in 1.75), with a main armour layer consisting of $90 \mathrm{t}$ concrete blocks overlying a mound composed of $25 \mathrm{t}$ blocks and a secondary mound of $6 \mathrm{t}$ natural riprap, all founded directly on the natural seabed without any prior dredging work being required. The breakwater head slopes at $50 \%(1$ in 2$)$ and is constructed with $90 \mathrm{t}$ blocks, reaching depths of $32 \mathrm{~m}$. The breakwater faces E $55^{\circ} \mathrm{S}$. It has a concrete parapet whose crest lies at elevation $18 \mathrm{~m}$.

(b) A $172 \mathrm{~m}$ long arm leading off at right angles from the final section of the breakwater, made up of two concrete caissons anchored at elevation $-15.00 \mathrm{~m}, 15.65 \mathrm{~m}$ wide, $20.00 \mathrm{~m}$ deep and 40.95 and $66.85 \mathrm{~m}$ long, respectively.

(c) A $1515 \mathrm{~m}$ long coastal wharf that was built in stages: $857.80 \mathrm{~m}$ were constructed at the first stage, leading off from the breakwater. This wharf is composed of concrete caissons founded at elevation $-22.00 \mathrm{~m}$. The wharf is $15.65 \mathrm{~m}$ wide, $24.00 \mathrm{~m}$ deep and $40.95 \mathrm{~m}$ long (10 units) and $66.85 \mathrm{~m}$ long (six units) and serves as an enclosure for the levelled area, having an effective surface area of 90 ha.

Before the caisson foundations were laid, around 10000 and $52000 \mathrm{~m}^{3}$, respectively, of rock and loose materials were dredged, down to elevation $-22 \cdot 00 \mathrm{~m}$.

Apart from the aforementioned works, the new harbour works involve the construction accesses by land and levelling the area around the harbour, as well as the electricity and water supply networks and so on.

\section{Description of the construction processes, layouts and works facilities and installations}

\subsection{Quarry: excavation, transport and grading}

A distinction was made between two types of ground when carrying out the quarry excavations (Figure 2): surface layer 
Port of Ferrol enlargement

works, Spain

de la Peña Zarzuelo

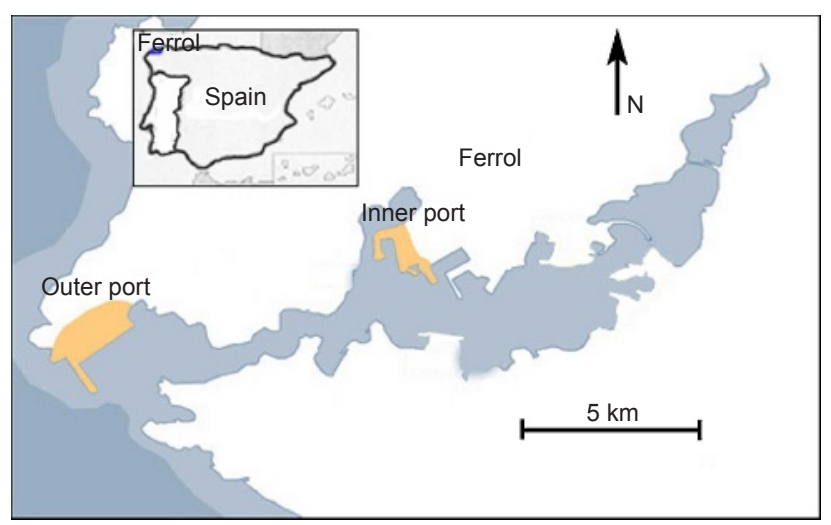

Figure 1. Port of Ferrol - location

and rock. The first of these included the layer of soil and the rock that has been weathered to such an extent that it can be excavated using mechanical resources. Explosives had to be used to excavate the second type of ground (rock).

Once the blasting had been completed, the loading and transport equipment (back diggers and dumpers up to $100 \mathrm{t}$; Figure 3) entered the quarry site, and groups of equipment were formed on the basis of the average cycles. However, they were generally made up of one back digger and two dumpers. At certain points in time, up to seven teams were working simultaneously.

The extracted material was classified in two stages. The first part of the process consisted of a preliminary classification being carried out by the loading resources in front of the quarry face, namely the dumper drivers selected what quarry

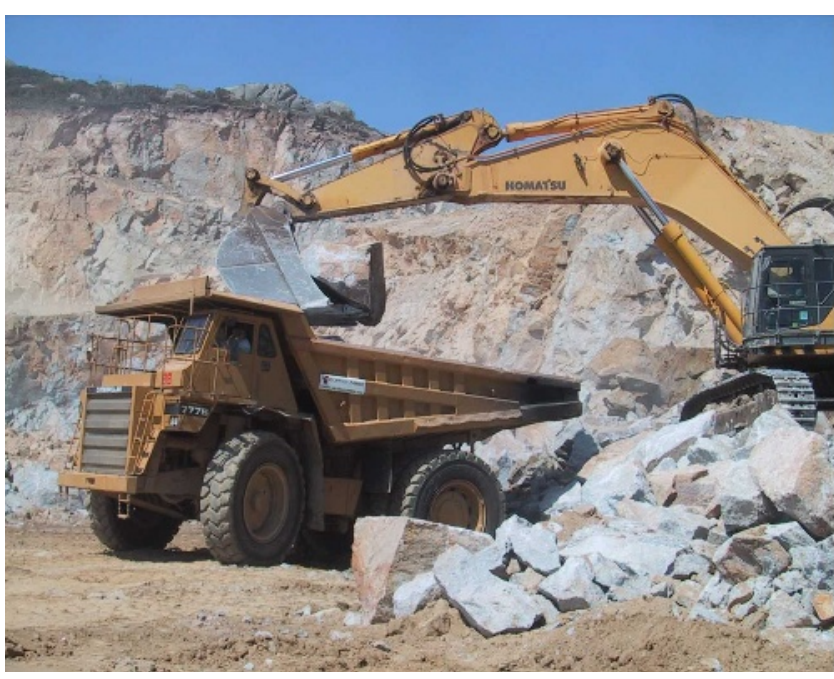

Figure 2. Equipment used for loading and transporting material stone was to be loaded (this being transported to intermediate stockpiling facilities where the second stage was carried out, the stone being classified into different sizes so that it could be controlled and verified), generally into ungraded material or general fill (which was deposited directly at the works site) or material to be sent to the aggregate classification and crushing plant.

\subsection{Breakwater}

\subsubsection{Auxiliary quay}

Before the construction work on the breakwater itself got under way, it was necessary to prepare a levelled area where a series of facilities could be fitted out that would make it possible to: (a) load the barges that were going to discharge the materials on the seabed, and (b) produce concrete to manufacture blocks, as well as to store these and classify the riprap for the construction of the breakwater.

A $150 \mathrm{~m}$ long auxiliary quay (Figure 4) was built for mooring purposes that could accommodate depths up to $4 \mathrm{~m}$ at low water springs level (LWSL), equipped with a loader that would make it possible to load several barges at the same time, regardless of the state of the tide. Two barges managed to moor at this auxiliary quay, one with a capacity for $650 \mathrm{~m}^{3}$ and the other with a capacity of $700 \mathrm{~m}^{3}$. A complete loading and unloading cycle lasted from 45 to $60 \mathrm{~min}$.

A temporary breakwater was built to provide sufficient shelter on the auxiliary quay; it was provided with an armour layer of natural stones weighing $6 \mathrm{t}$.

\subsubsection{Laying the material from the sea}

Each of the vessels was equipped with differential global positioning system (DGPS) antennae to assist them in

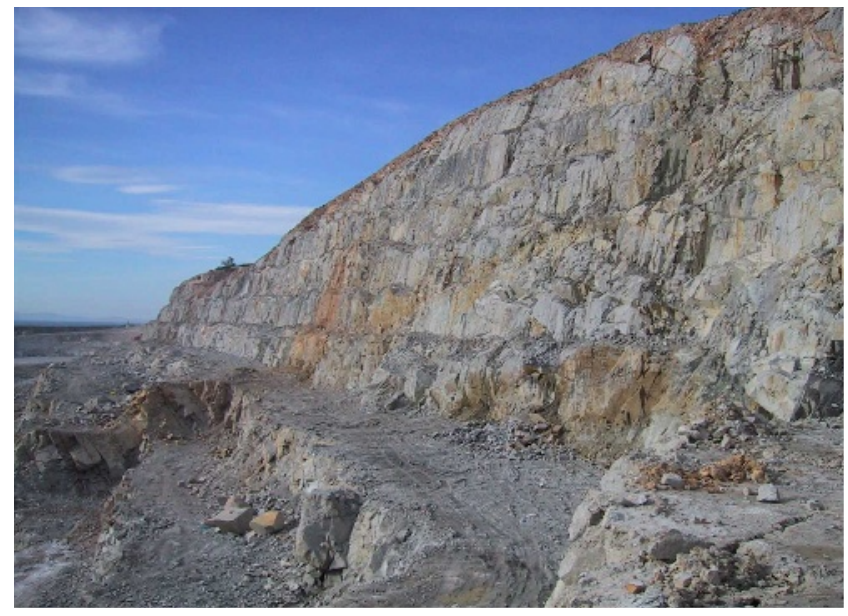

Figure 3. Close-up of the quarry face 
Maritime Engineering

Volume 164 Issue MA2
Port of Ferrol enlargement

works, Spain

de la Peña Zarzuelo

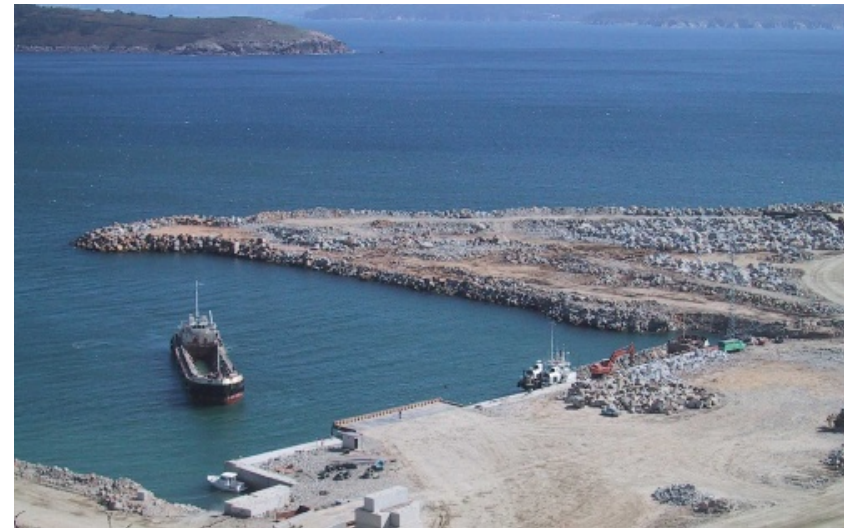

Figure 4. Auxiliary quay and breakwater leading off it

depositing the ungraded material for the core and when discharging the riprap (Figure 5). One of these antennae was used to establish the exact discharge point, whereas the second one established the alignment that indicated the direction that the barge was facing. The laying grids were programmed every day with the software concerned, and the entire process was controlled by the works management.

These maritime laying processes enabled the breakwater to progress as far as $-8.00 \mathrm{~m}$, as from that level the construction process began to be carried out with land resources (dumpers, bulldozers and cranes). It was thus possible to go ahead and make progress on the breakwater all the year round, thereby ensuring that the works performed would not be affected by stormy spells, because at those depths no failures take place.

It was possible to load the barges (Figure 6) by pouring directly out, where the ungraded material was concerned. In

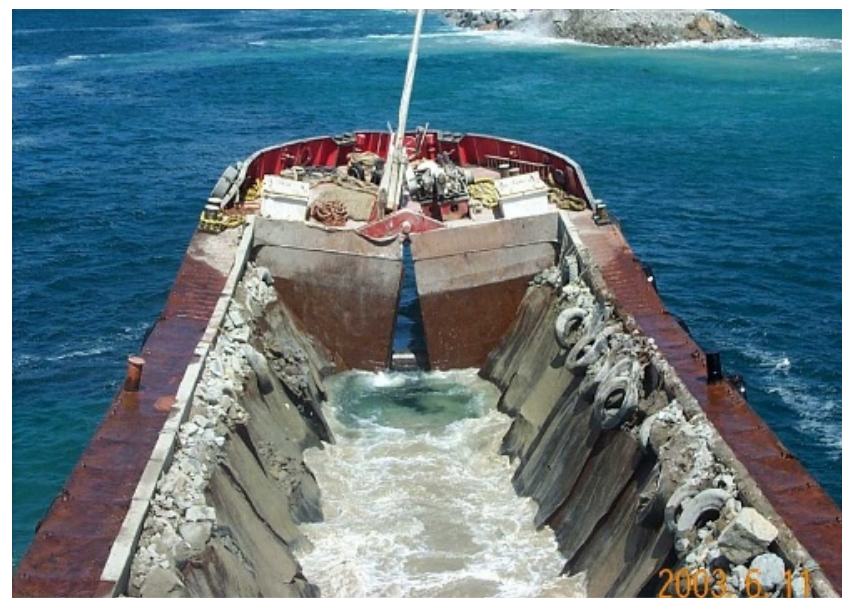

Figure 5. Depositing the riprap on the seabed

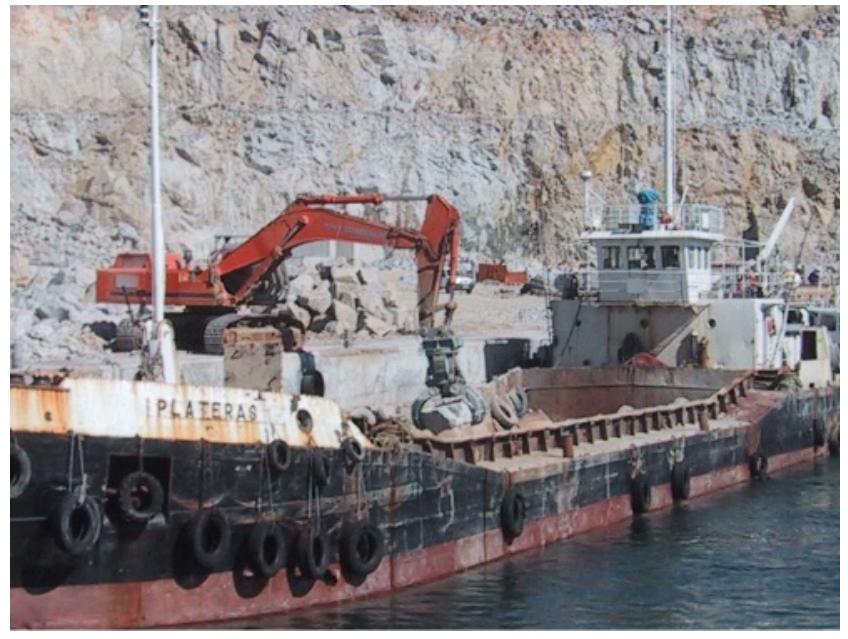

Figure 6. Loading a barge with a back digger from the auxiliary quay

the case of the riprap, however, this was done with the aid of a back digger, so that the vessels would not be damaged.

\subsubsection{Laying the material from dry land}

Once elevation $-8.00 \mathrm{~m}$ had been reached with the ungraded material, the dumpers took over to complete the sections that had been defined, as far as elevation $7.23 \mathrm{~m}$, the final elevation for the breakwater core, adopted using the criteria indicated below.

One of the critical processes for defining suitable production cycles is to establish a progress elevation that is sufficient to carry out the works under the local tide conditions $(+4.65 \mathrm{~m})$ and the average wave actions in the zone. It is also extremely important for safety reasons for the crest to be wide enough to enable two off-road vehicles to be driven on it at the same time and for them to be able to pass each other when one of them has the block-laying crane mounted on it. For this reason, the progress elevation was established at $7.23 \mathrm{~m}$ and the crest width at $21.00 \mathrm{~m}$.

Where the breakwater works were concerned, special importance was attached to the fact that it was not necessary to construct winter heads, because all the progress on land in the zone most exposed to wave action was made between April and September in the third year, the parapet being completed in December. This meant that the continuity of the construction process had to be guaranteed by having sufficient stockpiles of blocks and riprap when the initial section of the breakwater was started, so that the entire construction process could be completed in this period.

In spite of the above, a failure affected the breakwater at the initial stages (March 2002) and approximately $100 \mathrm{~m}$ of the 
Port of Ferrol enlargement

works, Spain

de la Peña Zarzuelo works were lost. However, the contracted company accepted liability for this risk in view of the fact that the first sections of the breakwater back onto the levelled areas of the harbour. However, the loss of material and effects on the progress of the works caused by the failure can be regarded as moderate and the economic repercussions were only slight. As will be analysed later, with reference to the dredging carried out to construct the wharf, the failure had a negative effect on the works, because pieces of riprap from the secondary armour layer fell into the caissons in the rubble-mound zone, and these had to be removed with the aid of a dipper.

Once the breakwater core had been completed with ungraded material, the different layers of riprap for the different filter layers were ready, and the same procedure was used as for the ungraded material (putting it in place with a barge as far as elevation $-8.00 \mathrm{~m}$ and using a dumper from that point on); the last part of the section defined in the project was given a finish and profiled with the aid of a crane equipped with a tray.

\subsubsection{Laying the blocks}

The $90 \mathrm{t}$ blocks were laid in place with a mobile caterpillar crane (Figure 7) with a maximum load capacity of $650 \mathrm{t}$ and maximum jib range of $112 \mathrm{~m}$, which was capable of laying 100 blocks per day, working round the clock. During the daytime, the crane was used to lay the blocks and at night it was used to lay the riprap with a tray.

Before each block was laid in place, its exact position had to be defined using the geographical positioning system (GPS), care being taken to ensure that the number of blocks laid per section complied with the porosity requirements and the number of layers established in the project. The control software installed in the operator's cabin was used for this purpose, and this made it possible to issue daily lists of the number of blocks laid and their exact positions; these activities were then checked by the works management.

Apart from the capacity and range factors, the type of crane was chosen on the basis of the versatility of its drive system. Mobile caterpillar cranes were used because such vehicles can be swiftly moved and withdrawn from their positions in the event of a sudden storm warning, which is not the case with other systems (cranes equipped with a ringer or superlift).

Another important factor that contributed to the progress made in constructing the breakwater was planning the production; this was done in such a way as to cause the least possible delay between layers once the progress elevation on land had been reached. The reason for this was to make it possible to react sufficiently well in advance, in the event of a warning being given about the imminence of a storm, so that

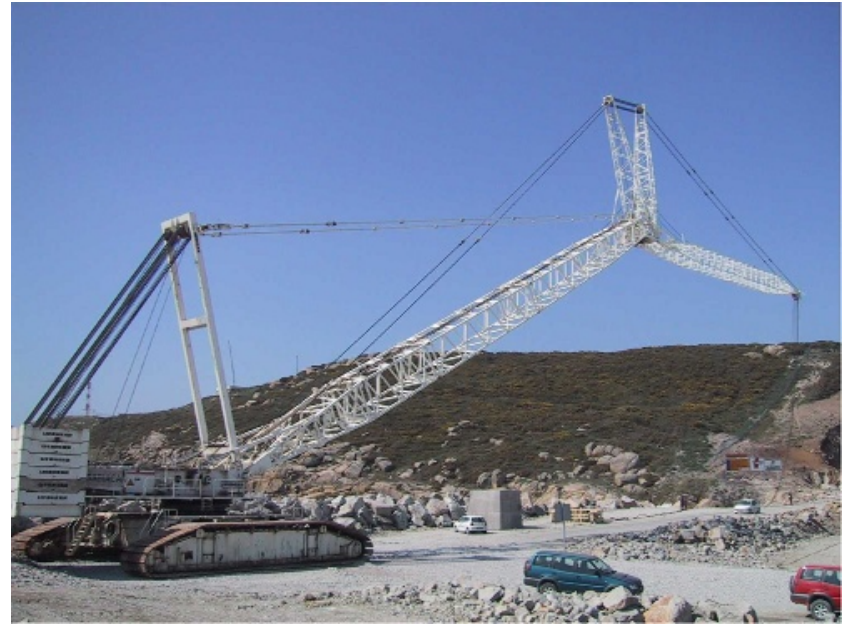

(a)

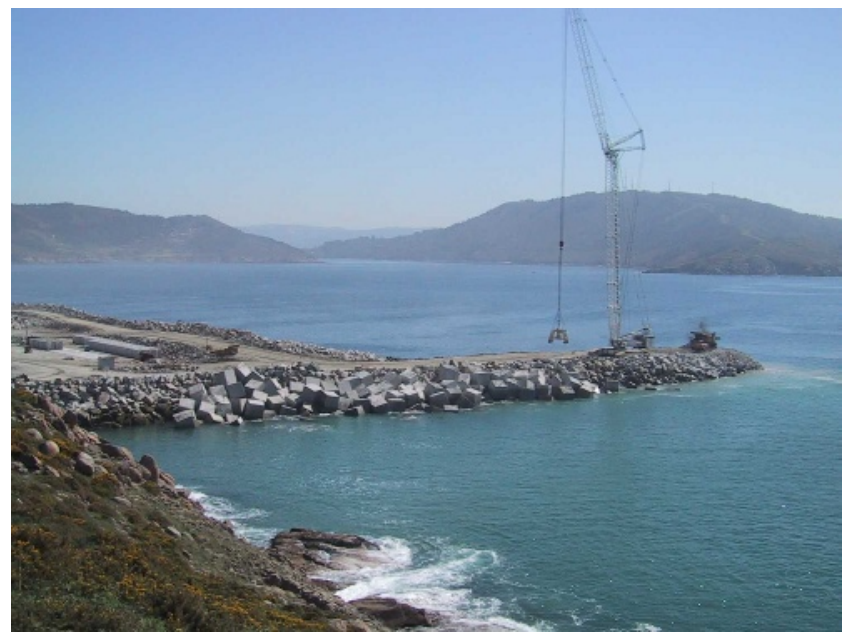

(b)

Figure 7. Crane laying blocks

the works that had been constructed up until that point could be protected from damage.

\subsubsection{Manufacturing aggregates and concrete}

One of the main characteristics of the works was that all the material required was manufactured at the in situ facilities, so it was essential to have aggregate grading and crushing plants on the site as well as concrete manufacturing facilities.

It must also be pointed out that for certain massed concretes (parapet and breakwater blocks) maximum aggregate sizes were used with dimensions that are larger than usual (up to $80 \mathrm{~mm}$ ). As will be analysed later, the sizes involved meant that the quality control processes for the concrete were rather more complex than usual, because the traditional test specimen setting processes for standard dimensions could not be used. 
Port of Ferrol enlargement

works, Spain

de la Peña Zarzuelo

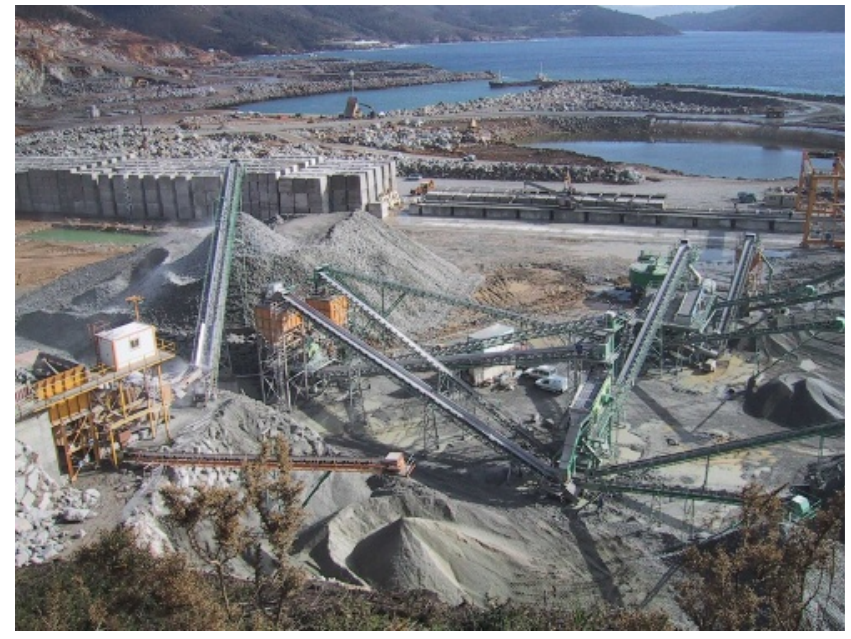

Figure 8. Aggregate manufacturing plant: at the end of the block yard and the auxiliary quay

A crushing plant with a production capacity of $300 \mathrm{t} / \mathrm{h}$ (Figure 8) was constructed in situ to produce the aggregates and subsequently manufacture the concrete. It produced six stockpiles whose sizes were 40/80, 25/40, 12/25 and 6/12 mm, plus two stockpiles of $0 / 6 \mathrm{~mm}$ (one washed and the other unwashed), as well as one stockpile of tailings (that were used for track and road maintenance works).

The final production at the plant was $1200000 \mathrm{t}$ of aggregates.

As the source material was granodiorite, its characteristics were such that for certain concretes (fundamentally those used for the caissons), it was necessary to obtain sands with improved qualities from beyond the works site and to give the concrete greater initial strengths and to facilitate the sliding process.

A concrete production plant with a capacity for manufacturing $150 \mathrm{~m}^{3} / \mathrm{h}$ (Figure 9) was installed on the works site. It consisted of two horizontal shaft forced mixers with a capacity of 45001 of dry concrete and two cement silos (100 t each) and a further two with a capacity of $1000 \mathrm{~m}^{3}$. The plant was designed with one loading ramp for each of the five hoppers that each provided one of the aggregate sizes and the tanks containing the additives used at each stage of the works.

\subsubsection{Manufacturing blocks}

Among the works construction procedure peculiarities were the design for the block yard and the way that the concrete was laid. It was produced directly from the centre and brought by 'ROTEC' conveyor belts, which obviated the need for concrete mixer lorries to cross the works and allowed for an ongoing concreting system with higher production.

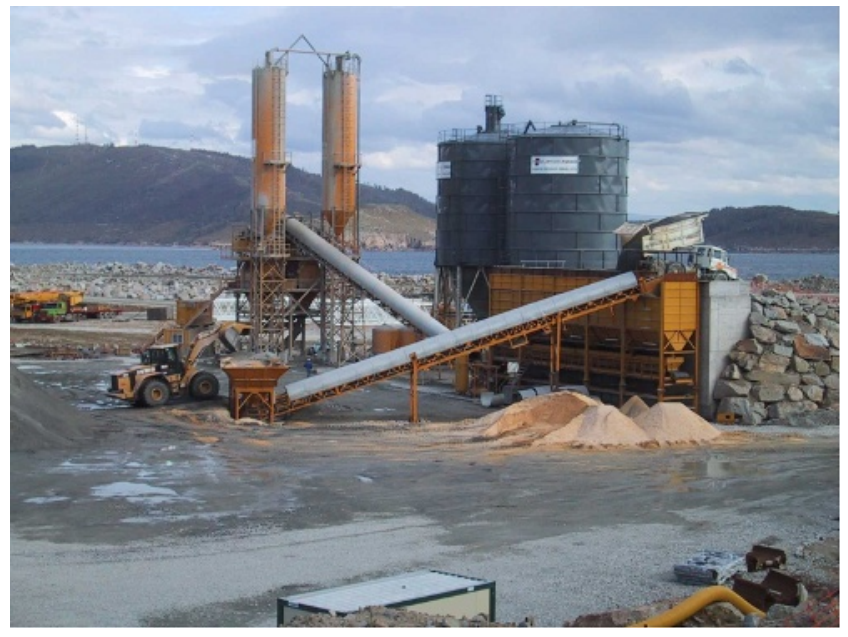

Figure 9. Concreting plant

This technology was successfully used to construct compactedconcrete dams, but no references have been found concerning their use in harbour structures. Therefore, if this is to be a competitive option in terms of cost using the traditional procedures, large quantities of concrete have to be laid in place in a zone where there is very little room to manoeuvre, so the lengths of the conveyor belts have to be shortened and there have to be special points where there are swaying movements, belt changes and so on, which are points where the weaknesses inherent to the process are to be found, because the concrete is exposed to the risk of segregation or desiccation.

The concreting facilities were split into the following activities.

(a) Hopper providing ongoing concrete supply. The hopper receives the concrete manufactured at the plant, so that it can be sent by perpetual screw/worm to a conveyor belt that leads to a small hopper that, in turn, puts the concrete on a conveyor belt again.

(b) Conveyor belt for transporting the concrete. The concreting is done by way of a conveyor belt (Figure 10) that is lying above a structure composed of $25 \mathrm{t}$ blocks, which are later used on the breakwater mound.

(c) Arm on caterpillar tracks for distributing concrete. A caterpillar tractor that can turn a complete circle $\left(360^{\circ}\right)$ and a telescopic distribution arm (Figure 11) that pours out the concrete inside the formwork.

(d) Compacting the concrete. Once the concrete has been poured it is vibrated, both manually (with needle vibrators) and mechanically by means of a back digger equipped with four long-range vibrators.

This system was used to pour the concrete directly into the formwork with the aid of a crawler or distributor arm. A total 
Port of Ferrol enlargement

works, Spain

de la Peña Zarzuelo

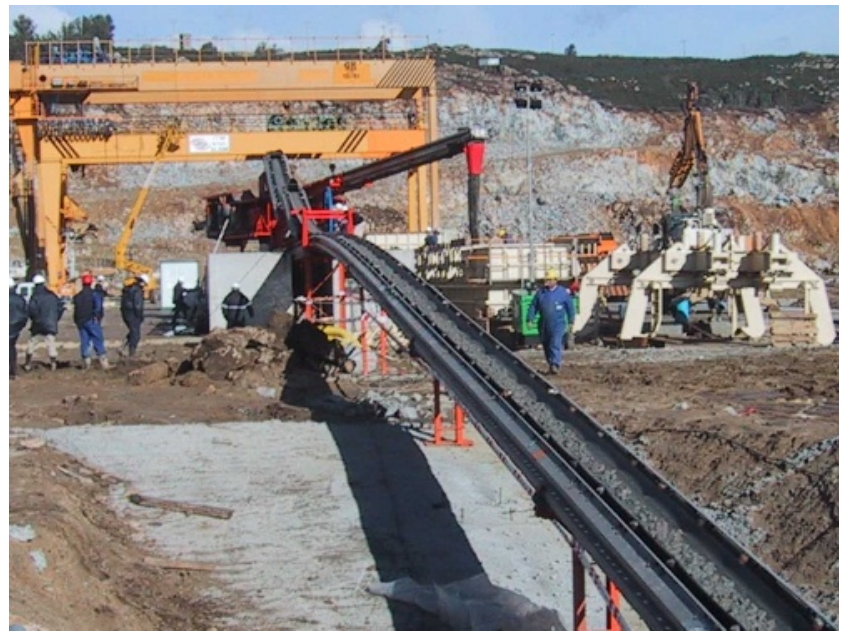

Figure 10. Close-up of the ROTEC conveyor belt

of five triple formworks were used in situ to manufacture $90 \mathrm{t}$ blocks and three quadruple formworks to manufacture the $25 \mathrm{t}$ blocks, in such a way that a total of fifteen $90 \mathrm{t}$ blocks and twelve $25 \mathrm{t}$ blocks were concreted for each post.

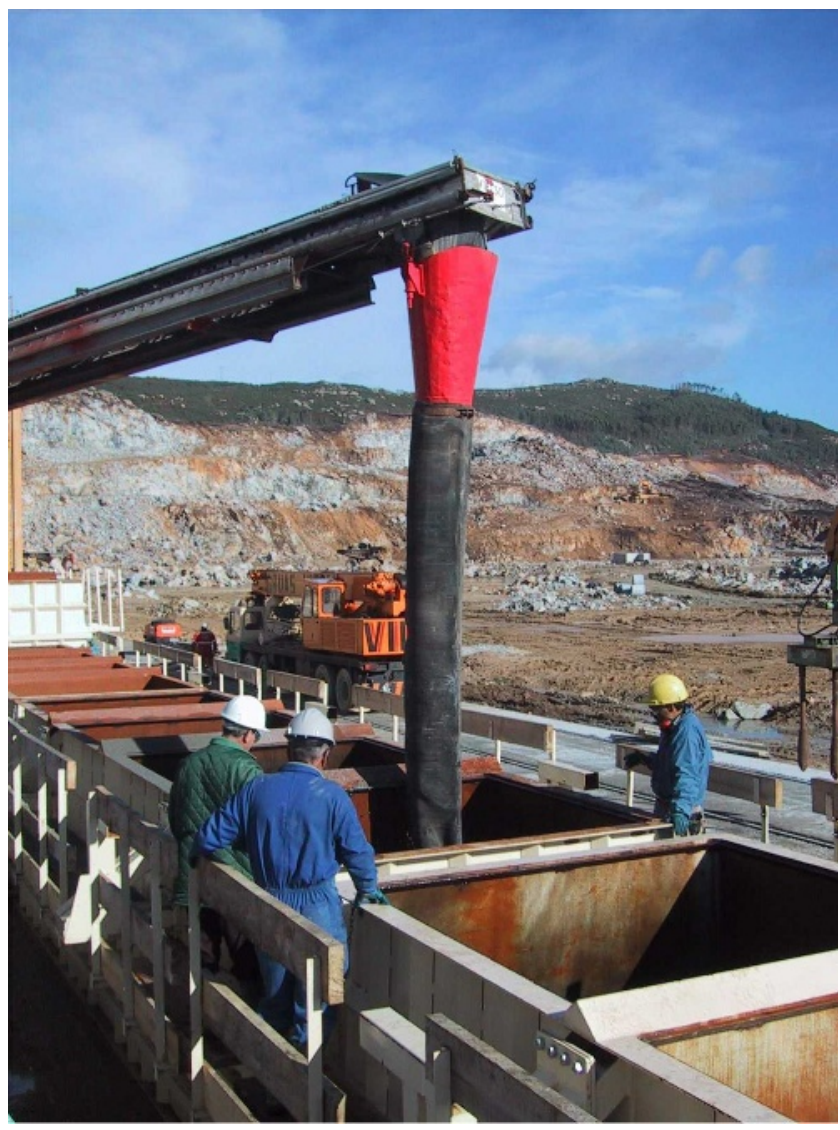

Figure 11. Close-up of the distributor arm or 'crawler'
A total of 7068 blocks weighing $90 \mathrm{t}$ and 6429 blocks weighing $25 \mathrm{t}$ were manufactured, three posts being completed every day. The concreting process lasted between 4 and $6 \mathrm{~h}$.

Once one post had been completed, namely after $6 \mathrm{~h}$, and as soon as the concrete had hardened sufficiently to be removed from the mould, the formwork was removed and work commenced on concreting a new post on the second of the manufacturing lines, arranged running parallel to the previous line. After $12 \mathrm{~h}$ had elapsed as from the start of the process, work began on concreting a new post, the third one, and work started on transporting the blocks that had been manufactured at the first post to the storage yard, as long as they were now strong enough to be raised by the grabbers in the gantry frame. The blocks then remained there for a minimum of 14 days, if the strengths so permitted, after which they were authorised to be laid in place on the works.

The block storage yard (Figure 12) was $300 \mathrm{~m} \times 35 \mathrm{~m}$ and covered an area of $10500 \mathrm{~m}^{2}$; it had a capacity to store a total of 678 blocks $(90 t)$ on three levels and 432 blocks ( $25 t$ ) on four levels, approximately one month's production working with two posts per day.

The first quarter of the block storage yard $(75 \mathrm{~m})$ was the manufacturing zone (the formwork was moved in parallel fashion along four concreting lines, two on either side of the ROTEC belts) and the remaining three-quarters was given over to stockpiling the manufactured blocks.

Two gantry cranes (Figure 13) running on rails were used to move the formwork and blocks. The first one had a capacity for handling $35 \mathrm{t}$, and its only function was to move the formwork between the four different manufacturing lines; it only moved around in the first quarter of the yard. The second one, with a handling capacity of $110 \mathrm{t}$, moved the blocks from

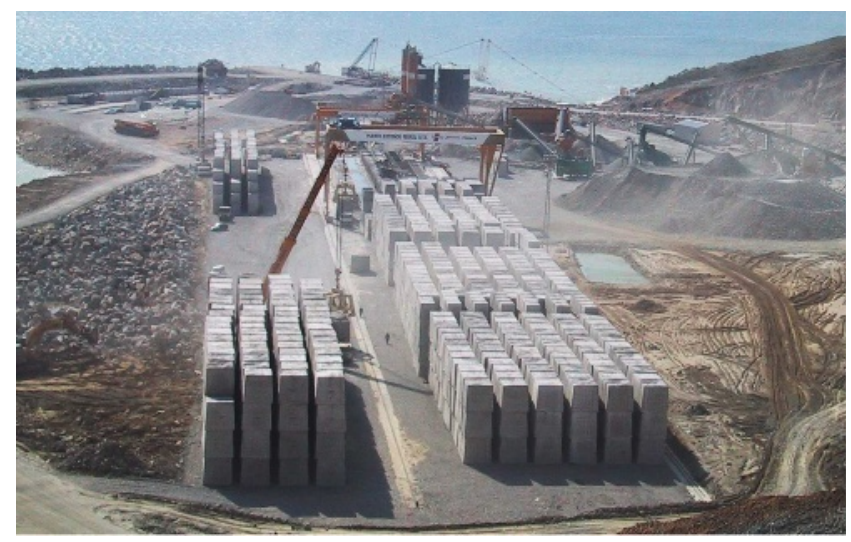

Figure 12. Block storage yard 


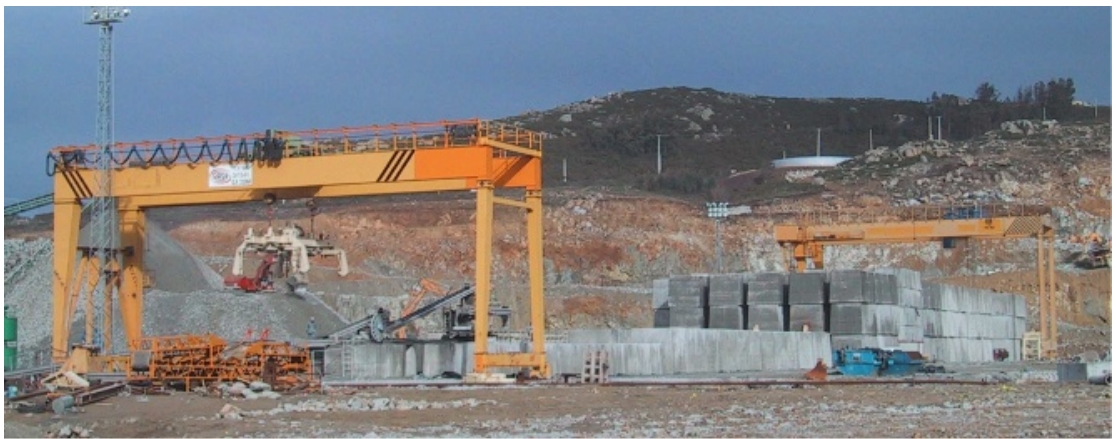

Figure 13. Close-up of the gantries used to move the blocks in the yard

the manufacturing zone to the stockpiling zone and from the stockpiling zone to the cradles that transported the blocks to the zone close to where they were to be laid in place. Therefore, the second crane moved around throughout the entire length of the yard.

The formwork was designed to be slightly conical to facilitate the process of removing the blocks from the mould, and the grabbers were designed to have a system of hydraulic jacks in the centre, which pushed the block inland, applying the pressure necessary to separate the block from the formwork without excessive friction.

As has already been pointed out, the statistical laws for the concrete strength curves (age and strength) were obtained so that the block storage yard would not have to be too large; this meant that by obtaining test specimens that set after 1, 3 and 7 days, it could be guaranteed that a block whose strength after
7 days was greater than $22 \mathrm{MPa}$ when an additive to speed up the process was used, or was greater than $20 \mathrm{MPa}$ if a superflux were used, would reach the $30 \mathrm{MPa}$ required in the instructions after 28 days. In such cases authorisation was given to lay the blocks after 14 days (when there was sufficient traceability for the strength of each block).

Two cradles were used to transport the blocks from the yard to the breakwater.

\subsubsection{Constructing the superstructure}

The parapet was constructed in five stages: foundation, slab, body (two stages) and cantilever/wave-return wall. Metallic formwork was used for the foundations and the slab. Sliding formwork moved by gantries was used on the construction process. The front of the gantries was supported on the lower stage and the rear on the back part of the same stage once the concrete was sufficiently hard (Figures 14 and 15).

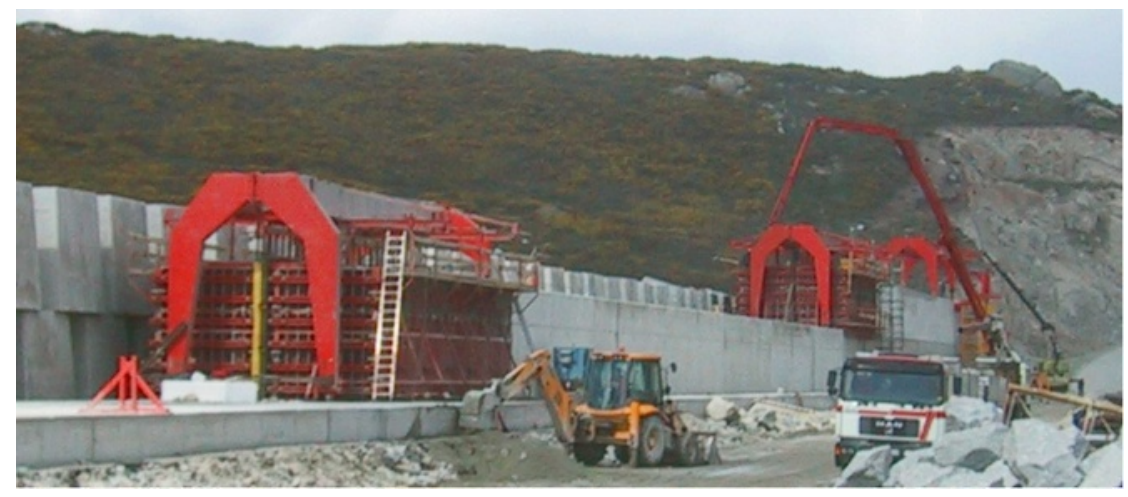

Figure 14. Close-up of how the parapet construction work was progressing 
Port of Ferrol enlargement

works, Spain

de la Peña Zarzuelo

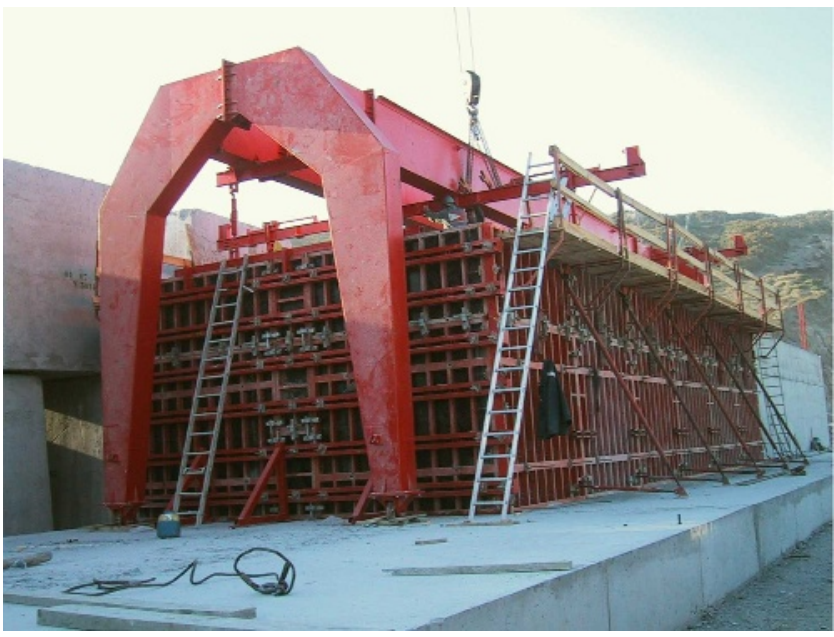

(a)

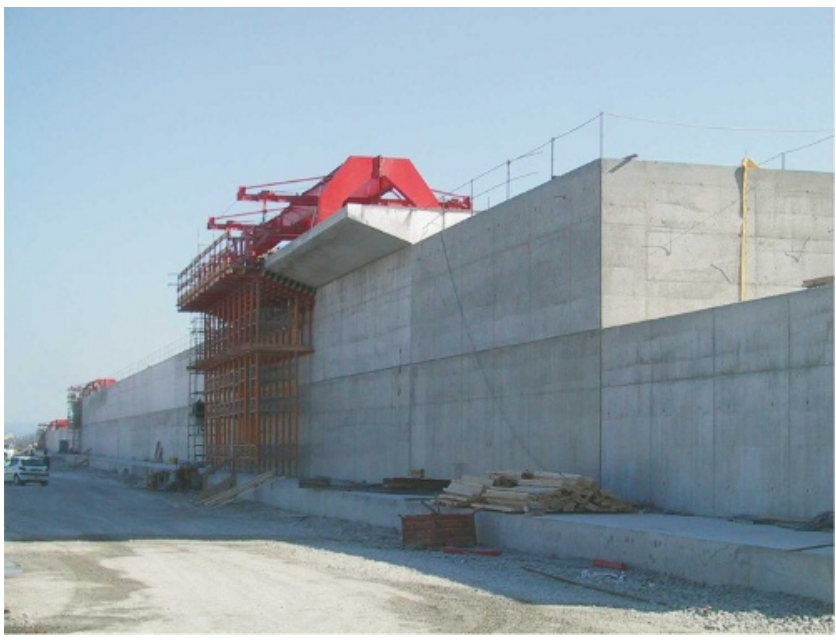

(b)

Figure 15. Close-up of the sliding formwork used for the parapet

The concreting for the breakwater body was done using conveyor belts and lorries and it was pumped for the cantilever/wave-return wall.

\subsection{Constructing the wharf}

\subsubsection{Riprap and fills}

The procedure followed for laying the riprap in place was the same as was used when constructing the breakwater.

The general filling was done using the closure dam procedure, which made it possible to create zones with material of a certain weight that protected the finer material which was poured inside.

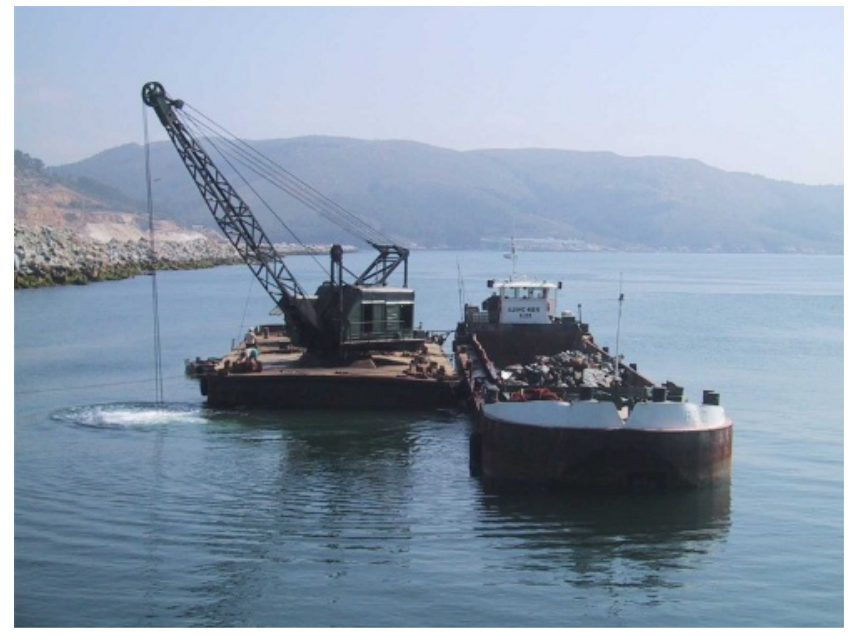

Figure 16. Extracting material dredged in rock

The selected fill material was poured in, spread out and compacted in successive layers, which were $50 \mathrm{~cm}$ thick for the lower beds and $20 \mathrm{~cm}$ thick for the upper ones.

\subsubsection{Structure: caissons}

Before the caissons that form the wharf were laid in place, the caisson foundation trench was dredged in the zones where the seabed lay above elevation $-22 \mathrm{~m}$. A suction dredger was used for loose materials and a pontoon and explosives were used for dredging in rock. As has already been pointed out, it was also necessary to use a dipper for dredging the riprap that fell into the trench after a stormy spell. The material obtained from the dredging activities was used for beach replenishment and regeneration and shellfish beds lying further inside the ria, as

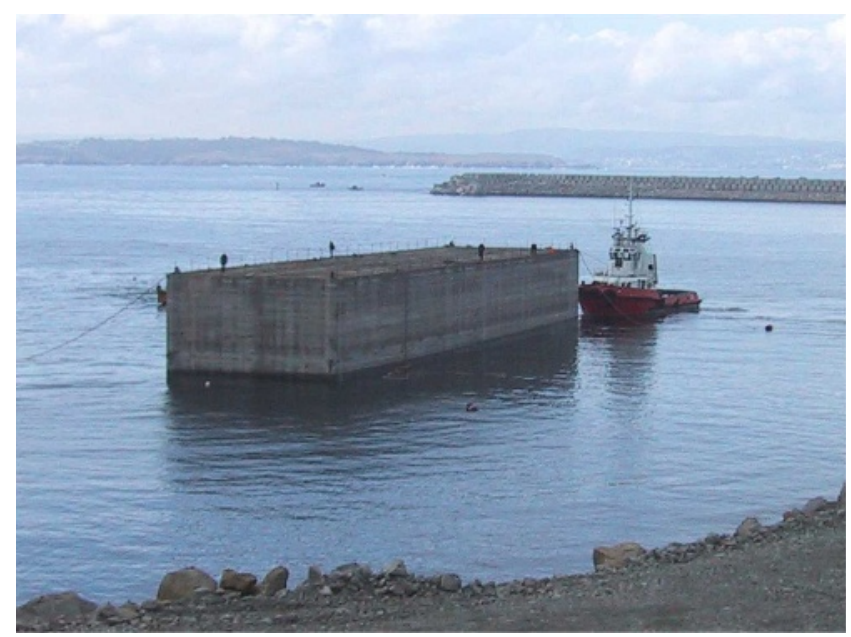

Figure 17. Close-up of the caisson laying process 
Port of Ferrol enlargement

works, Spain

de la Peña Zarzuelo

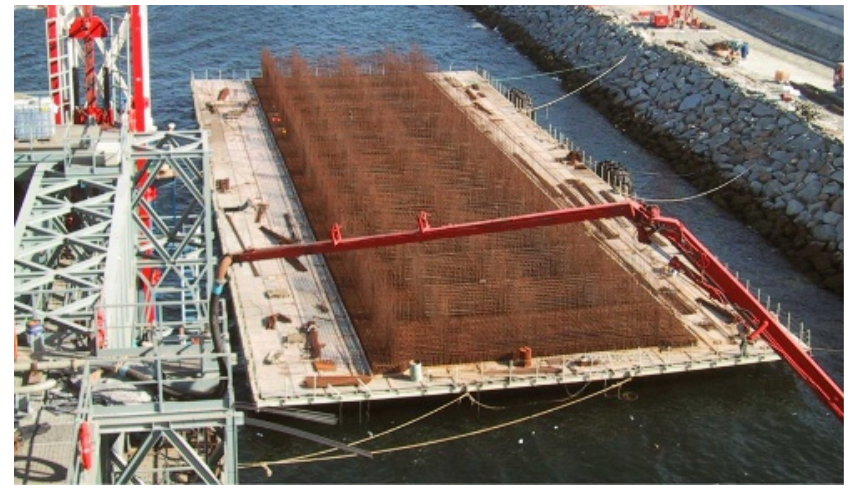

Figure 18. Preparing the footing for the wharf caissons

well as for other uses in situ: filling cells and trenches (Figure 16)

Once the trench had been completed, work started on laying and levelling the material for the mound, a barge being used for the former and a dredger being used for the latter. A diving team was then employed to finish off the work with pontoon teams on the surface. The mound elevation was $-20.00 \mathrm{~m}$.

Everything was ready for the caissons to be sunk (Figure 17) once the mound work had been completed. The way the caissons were laid in place depended on the sea conditions, but auxiliary vessels

\begin{tabular}{lccc}
\hline & Caisson & $\begin{array}{c}\text { Metres slipped } \\
\text { per day }\end{array}$ & $\begin{array}{c}\text { Metres slipped } \\
\text { per } \mathrm{h}\end{array}$ \\
\hline Type 1 Caisson & 1 & $3 \cdot 343$ & $0 \cdot 139$ \\
$66.85 \times 5 \cdot 65$ & 2 & $3 \cdot 150$ & $0 \cdot 131$ \\
$\times 24 \cdot 00$ & 3 & $4 \cdot 103$ & $0 \cdot 171$ \\
& 4 & $4 \cdot 426$ & $0 \cdot 184$ \\
& 5 & $4 \cdot 440$ & $0 \cdot 185$ \\
& 6 & $4 \cdot 821$ & $0 \cdot 201$ \\
Type 2 Caisson & 7 & $4 \cdot 775$ & $0 \cdot 199$ \\
$\times 24.00$ & 8 & $5 \cdot 450$ & $0 \cdot 227$ \\
& 9 & $4 \cdot 846$ & $0 \cdot 202$ \\
& 10 & $5 \cdot 500$ & $0 \cdot 229$ \\
& 11 & $5 \cdot 727$ & $0 \cdot 239$ \\
& 12 & $5 \cdot 730$ & $0 \cdot 239$ \\
& 13 & $6 \cdot 027$ & $0 \cdot 251$ \\
& 14 & $5 \cdot 425$ & $0 \cdot 226$ \\
& 15 & $6 \cdot 109$ & $0 \cdot 255$ \\
& 16 & $5 \cdot 836$ & $0 \cdot 243$ \\
& 17 & $6 \cdot 136$ & $0 \cdot 256$ \\
& 18 & $6 \cdot 000$ & $0 \cdot 250$
\end{tabular}

Table 1. Caisson manufacturing performance obtained

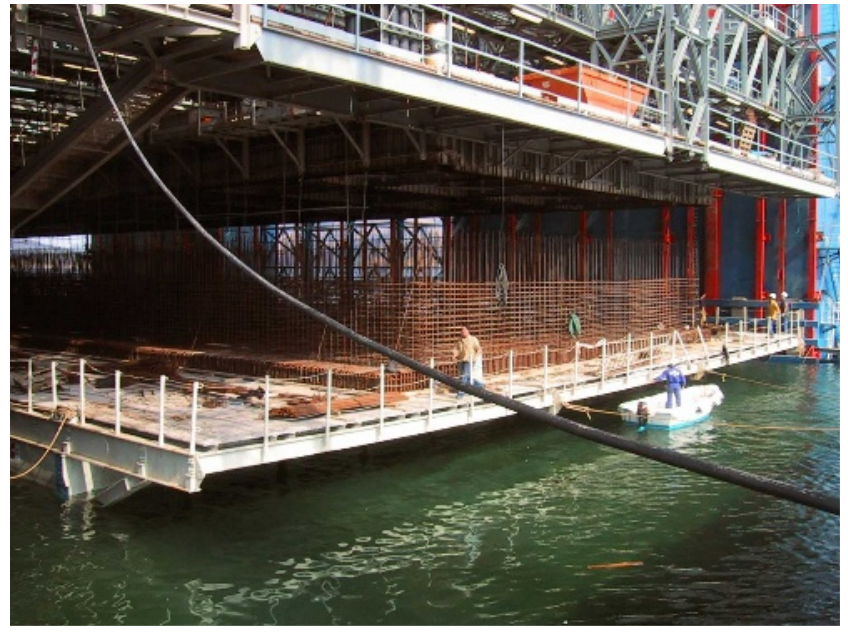

Figure 19. Close-up of the steel reinforcements being suspended in the floating dock umbrella

and tractels were used on days when the sea was not very rough, whereas tugs were brought in to help in choppier conditions.

The breakwater-wharf connection had to be completed before the first caisson was laid in place. A structure had to be created at that section that allowed for a transition between a sloping section of the breakwater and its armour layer, and the vertical section of the wharf. This was achieved by constructing a 'U'shaped wall composed of approximately 300 pieces of concrete each weighing $5.7 \mathrm{t}$, in the form of a double ' $\mathrm{T}$ '; this wall was then filled with submerged concrete and general fill. The aforementioned point of union provided the surface area

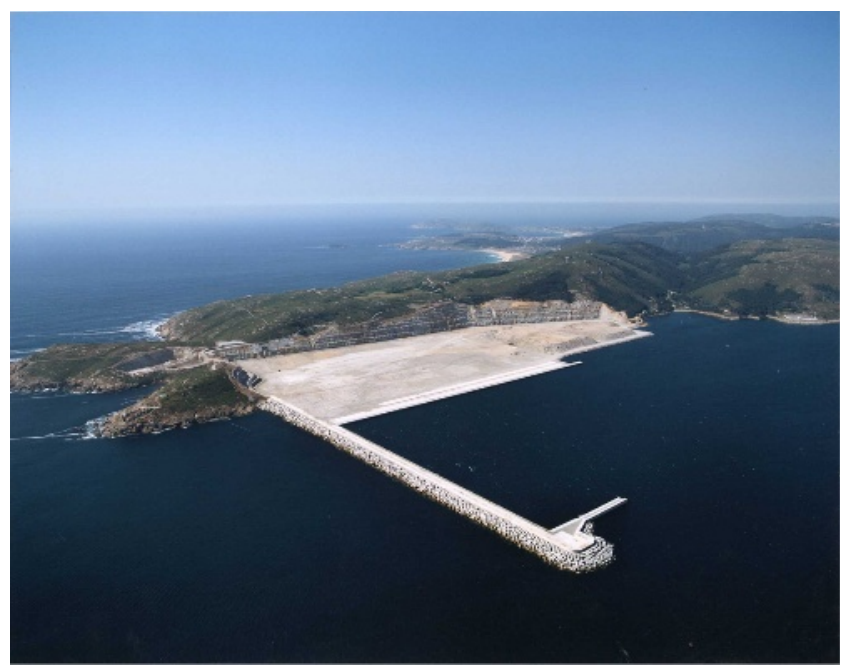

Figure 20. Final state of the works, August 2004 
required to moor the floating docks and to install the pumping equipment needed to concrete the caissons.

A total of 18 caissons were prepared, 16 for the wharf and two for the arm. Two floating docks were used in the process. Caissons $66.85 \mathrm{~m}$ long, $17.65 \mathrm{~m}$ wide (including footing) and $24.00 \mathrm{~m}$ deep were made using the larger floating dock. The caissons manufactured with the smaller one were the same width and depth, but were only $40.96 \mathrm{~m}$ long. The caissons for the arm were the same length $(66.85$ and $40.96 \mathrm{~m})$ and width, so that the same formwork could be used, but in this case they were only $20 \cdot 00 \mathrm{~m}$ deep.

The caisson construction and laying process took place in two overlapping stages. First of all, the work began on the adjacent pontoon (Figure 18), where all the steel for the caisson footing was assembled and mounted, together with the most reinforced part and the initial metres of the caisson walls. These tasks took 2 days to complete. The concreting and reinforcing of the wall for the other caisson was carried out simultaneously inside the floating dock.

Once the footing had been reinforced, and with the floating dock in its ballast position, the pontoon was inserted inside the floating dock. The steel reinforcement structure for the footing was then suspended from the caisson wall formwork, which was supported by a series of gantry cranes that then made the formwork slide along (Figure 19). The ballast was removed from the floating dock once the metallic structure was supported, and as soon as the top was lying above sea level the metallic structure was supported on it. Immediately after that, and while the footing formwork (60 $\mathrm{cm}$ high) was being assembled, the metallic reinforcements for the first metres of the caisson walls were inserted into the formwork and the exterior of the caisson cells. When all the reinforcements were in place the footing was concreted.

Once the footing was concreted, the formwork was lowered down to the crest and work started on applying it to the caisson wall $(23.60 \mathrm{~m})$. The formwork was slid at a rate ranging from $0 \cdot 20$ to $0.25 \mathrm{~m} / \mathrm{h}$, approximately, so the floating caisson was constructed in around 6 days. Table 1 shows the performances obtained for each one of the caissons.

\subsubsection{Constructing the superstructure}

Sliding formwork was used for the section of each one of the parts when concreting the edge beam, and the intermediate and rear beams.

The concrete pavement was constructed after spreading and compacting with a laser-controlled screed machine - lanes up to $6 \mathrm{~m}$ wide being concreted, with transverse joints every $5 \mathrm{~m}$.

\subsection{Other facilities}

A total of three weighing machines were installed at different points in the harbour with a view to controlling and measuring the riprap. Two of the weighing machines were $7 \mathrm{~m} \times 7 \mathrm{~m}$ and had a capacity for $180 \mathrm{t}$, so that they could weigh the dumpers, and one was a mixed weighing machine $(7 \mathrm{~m} \times 14 \mathrm{~m})$ for weighing the dumpers and cradles that weighed up to a capacity of $180 \mathrm{t}$.

Other auxiliary items and services were provided, such as works transformers, electricity lines, a $2000 \mathrm{~m}^{3}$ water tank, so that supplies could be guaranteed at the caisson construction stage, complete quality control laboratories equipped with all the items necessary and facilities needed to control the concrete (wet chamber, press, etc.), car parks and yards for repairing the machinery, works huts with changing rooms, first aid facilities and a canteen (Figure 20).

\section{REFERENCE}

Grassa Garrido JM, Gutiérrez-Serret R, Martín Soldevilla MJ, Ruiz Mateo A and Santás López JC (2009) Ferrol outer port: experimental and in situ design studies. Proceedings of the Institution of Civil Engineers - Maritime Engineering 162(2): $57-72$.

\section{WHAT DO YOU THINK?}

To discuss this paper, please email up to 500 words to the editor at journals@ice.org.uk. Your contribution will be forwarded to the author(s) for a reply and, if considered appropriate by the editorial panel, will be published as discussion in a future issue of the journal.

Proceedings journals rely entirely on contributions sent in by civil engineering professionals, academics and students. Papers should be 2000-5000 words long (briefing papers should be 1000-2000 words long), with adequate illustrations and references. You can submit your paper online via www.icevirtuallibrary.com/content/journals, where you will also find detailed author guidelines. 